\title{
RELATIONSHIP OF PARENTING PATTERNS AND INTEREST TOWARDS MUSIC LEARNING OUTCOMES OF CLASS VIII STUDENTS SMP NEGERI 2 BREBES
}

\author{
Siti Aesijah ${ }^{凶}$ \\ Fakultas Bahasa Dan Seni, Universitas Negeri Semarang, Indonesia \\ Astrio Dinarti Aulia Dewi \\ Fakultas Bahasa Dan Seni, Universitas Negeri Semarang, Indonesia \\ Nafik Salafiyah \\ Fakultas Bahasa Dan Seni, Universitas Negeri Semarang, Indonesia
}

\section{Article Info \\ Submitted : April, 2021 \\ Revised : May, 2021 \\ Accepted : May, 2021}

Keywords:

parenting style, interest in learning, learning outcomes

\begin{abstract}
The results of study are influenced by some factors. Parenting patterns and learning interests are factors that influence Music learning outcome. The formulation of the problem in this study is (1) whether there is a relationship between parenting patterns on the learning outcomes of Music Arts; (2) whether there is a relationship between interest in the learning outcomes of Music; (3) whether there is a relationship between parenting patterns and interest in the learning outcomes of Music. The purposes of the study were (1)to find out whether there is a relationship between parenting styles and learning outcomes in music; (2) to know whether there is a relationship of interest to the learning outcomes of music; (3) to find out whether there is a relationship between parenting patterns and mutual interest in the results of learning music. The results showed that: (1) there was a positive relationship between parenting style and learning outcomes in Music, with the interpretation of the closeness of the correlation showing a small category, which was $9.48 \%$; (2) there was a positive relationship between interest in the learning outcomes of Music, with the interpretation of the closeness of the correlation indicating the sufficient category, which was $11.42 \%$; (3) there was a positive relationship between parenting and interest in the learning outcomes of Music, with the interpretation of the closeness of the correlation indicating the sufficient category, which was $37.82 \%$. The conclusion of this study was that there was a positive and significant relationship between parenting and interest together on the learning outcomes of Music. The application of parenting with a democratic attitude by paying attention, caring, and respecting children's freedom, as well as guiding with understanding can create conditions for children to study music diligently, both in theory and practice. Thus, children's music learning outcomes can certainly increase.
\end{abstract}




\section{INTRODUCTIONS}

The parenting pattern is one way to build a right character of children and family also plays an important role to implement discipline, such as Father, mother, brother, sister, grandpa, and grandma. "Parents are the first teacher for children. Wise parents are those who provide a wide opportunity to their children to be developed under parents' control. Parents as teacher of course has a way to educate their children, it is what we called parenting pattern." (Arief, 2006).

Ratna Ningrum, W. (2018) states that parents should be able to guide their children to be able to differenciate between the good and not good, the do and don't. That is why, family education, such as moral values and faith should be built earlier because it is basic of life.

Due to the pandemic situation, the parents' role becomes major thing. Many forms of parenting patterns will imply to build children's character. Parents are the nearest environment for children, they watch their parents' attitude everyday even imitate it. This condition has positive and negative effects toward the children's development. If the child is often criticized, it will be easy to blame others; if he often gets insulted, he will grow up to be a shy person; if you get tolerance, you will become a patient person; Likewise, if you live with praise, you will develop respect for yourself and for others (Kuswanti et al., 2020).

(Slameto, 2015) Explains that interest is a feeling of preference and attachment to something or an activity without being told. Interest is basically the acceptance of a relationship between oneself and something outside oneself. The stronger or closer the relationship, the greater the interest. Interest is one of the drivers in achieving learning outcomes.

Basically, the success or failure of student achievement in realizing educational goals depends on the learning process they experience, both in the school and family environment, especially on parenting pattern to children. In accordance with pre-research activities, through interviews, questionnaires, and documents in the form of learning outcomes at SMP Negeri 2 Brebes, the researchers found that learning music is one of the subjects that students are interested in. This is evidenced by every Musical Art learning activity that pleases students and is enthusiastic in participating in learning. In addition, the learning facilities for Musical Arts are very adequate so as to support the teaching and learning process. As for the factor of educators being professional and competent teachers in their fields, it can be seen from the teaching methods that are innovative and creative so that they support students to be more interested in the learning process.

\section{METHODS}

This research is quantitative and belong to correlation type. Hamdi, (2014) discusses a research that emphasizes on objective phenomena that is studied quantitatively and the design using numbers, statistic processing. The research target was the students of SMP Negeri 2 Brebes grade VIII. The sampling technique in this study used the Simple Random Sampling method. The variables in this study consisted of two independent variables, namely parenting patterns and interest in learning and one dependent variable, namely the learning outcomes of Musical Arts.

Data collection techniques using
questionnaire documentation. The questionnaire in this study was used to find out information about parenting patterns and learning interests possessed by each student, while the learning outcomes of Musical Arts were obtained from the results of the Mid Semester Assessment for the 2019/2020 school year. Before the research instrument was used, a trial was conducted. Furthermore, the researchers tested the validity and reliability of the instrument. The data analysis techniques used in this study are: (1) prerequisite tests include normality test, linearity test, and multicollinearity test; (2) descriptive statistical analysis; and (3) analysis of hypothesis testing using simple correlation test, multiple correlation test, significance test or F test, and coefficient of determination test.

\section{RESULTS AND DISCUSSION}

Tridhonanto (2014:5) states that states that parenting is the whole interaction with children where parents give encouragement to change behavior, knowledge and values that are considered the most appropriate for parents so that children can be independent, have high curiosity, be friendly, and success oriented. 
Suprijono (2014:5) said that learning outcomes are patterns of actions, values, understanding, appreciation, attitudes, and skills.

Descriptive analysis is used to describe the data from each variable. In this study, the description of the data presented includes a description of the independent variable data, namely parenting patterns and interest in learning as well as a description of the dependent variable data, namely the learning outcomes of music art for class VIII students of SMP Negeri 2 Brebes.

\section{Results of Descriptive Analysis of Parenting PatternVariables $\left(\mathbf{X}_{1}\right)$}

The parenting style data was obtained based on a questionnaire consisting of 36 statement items. The results of the parenting style questionnaire can be seen in the following table:

\begin{tabular}{cccc}
\hline Score & Total & Precentage & Category \\
\hline $36 \leq S T<63$ & 0 & $0 \%$ & Poor \\
\hline $63 \leq S T<90$ & 2 & $3,12 \%$ & Enough \\
\hline $90 \leq S T<117$ & 32 & $50 \%$ & Good \\
\hline $117 \leq S T \leq 144$ & 30 & $46,875 \%$ & Very Good \\
\hline Total & 64 & $100 \%$ & \\
\hline
\end{tabular}

Table 1

Category Parenting Pattern

Based on these calculations, the maximum score is 144 , the minimum score is 36 , the class range is 108 , and the class length is 27 .

\section{Results of Descriptive Analysis of Learning Interest $\left(\mathbf{X}_{2}\right)$}

Interest in learning data was obtained based on a questionnaire consisting of 42 statement items. Interest in learning can be seen in the following table:

\begin{tabular}{cccc}
\hline Sscore & $\begin{array}{c}\text { Total of } \\
\text { Students }\end{array}$ & Precentage & Category \\
\hline $\begin{array}{c}42 \leq S T \\
<74\end{array}$ & 0 & $0 \%$ & Poor \\
\hline $\begin{array}{c}74 \leq S T< \\
106\end{array}$ & 2 & $3 \%$ & Enough \\
\hline $\begin{array}{c}106 \leq S T< \\
138\end{array}$ & 23 & $36 \%$ & Good \\
\hline $\begin{array}{c}138 \leq S T \leq \\
168\end{array}$ & 39 & $61 \%$ & Very Good \\
\hline Total & 64 & $100 \%$ & \\
\hline \multicolumn{3}{c}{ Table 2 } \\
& Learning Interest Category
\end{tabular}

Based on the above calculation, the maximal score is 168 , the minimal score is 42 , the class range is 126 , the class length is 32 .

\footnotetext{
The Results of Descriptive Analysis of Music Learning Outcome (Y)
}

The results of Music learning outcome in this research is gained from mid-even semester assessment in the academic year of 2019/2020.

\begin{tabular}{cccc}
\hline Num. & $\begin{array}{c}\text { Interval } \\
\text { Class }\end{array}$ & Frequency & $\begin{array}{c}\text { Precentage } \\
\mathbf{( \% )}\end{array}$ \\
\hline 1. & $80-84$ & 13 & $20,3 \%$ \\
\hline 2. & $85-89$ & 13 & $20,3 \%$ \\
\hline 3. & $90-94$ & 18 & $28,1 \%$ \\
\hline 4. & $95-100$ & 20 & $31,3 \%$ \\
\hline \multicolumn{4}{c}{ Total } \\
\hline \multicolumn{4}{c}{ Category of Music Learning Results }
\end{tabular}

Based on these calculation, it is obtained thet data percentage is $31,2 \%$ at the interval class of $95-100$ and the smallest percentage is 20,35 , at the interval class range of 80-24 and 85- 89 .

\section{The Results of Prerequisite Test, Normality Test}

The normality test is hold to know the data in every variable that is analyzed in normal distribution (Sugiyono, 2017). This normality test in this research refers to Kolgomorov-Smirnov test model. Based on the results of the normality test, the significance value of Asymp.Sig (2-tailed) was 0.200 where the significance value was greater than 0.05. It was concluded that the data were normally distributed. Thus, the assumptions or requirements for normality have been met.

\section{Linearity Test}

The linearity test of the parenting style variable with the learning outcomes of Musical Arts obtained a significance value of Deviation from Linearity $0.611>0.05$, so it can be concluded that there is a linear relationship between the parenting style of parents and the learning outcomes of Musical Arts. While the linearity test for the variable interest in learning with learning outcomes in Music obtained a significance value of Deviation from Linearity $0.214>0.05$. It can be concluded that there is a linear relationship between interest in learning and learning outcomes in Music.

\section{Multicollinearity Test}

From the results of the multicollinearity test, it is known that the value of VIF (Variance Inflation Factor) of the two independent variables, namely parenting patterns and interest in learning is 1.288 where the value is less than 10 and the Tolerance value is 0.776 more than 0.10 , it can be concluded that the independent variables did not occur. multicollinearity.

\section{Hypothesis Analysis}


Hypothesis analysis in this study uses simple correlation analysis, multiple correlation analysis, significance test ( $\mathrm{F}$ test), and coefficient of determination test.

\section{The Relationship of Parenting Patterns to Music Learning Outcomes}

The simple correlation test in this study uses the product moment correlation test with the help of the SPSS for Windows series 23 program. The calculation results can be seen in the following table:

\begin{tabular}{crrrr}
\hline \multicolumn{4}{c}{ Model Summary } \\
\hline Model & $\mathrm{R}$ & R Square & $\begin{array}{c}\text { Adjusted R } \\
\text { Square }\end{array}$ & $\begin{array}{r}\text { Std. Error of } \\
\text { the Estimate }\end{array}$ \\
\hline 1 &, $615^{\mathrm{a}}$ &, 378 &, 358 & 5,332 \\
\hline
\end{tabular}

Table 4

Parenting Pattern Correlation Test Results on Learning Outcomes

Table 4 shows the results of a simple correlation test between the parenting style variable and the musical learning outcome variable of 0.308 . These results show a positive number and the value of the coefficient ( $r$ ) in the study is included in the sufficient category based on the interpretation of the correlation coefficient. At the 0.05 significance level, it is known that the significance value from table 4.18 is $0.00(0.000 .05)$, so the correlation is said to be significant. The results of these calculations indicate that $\mathrm{Ha} 1$ is accepted, the application of parenting patterns with democratic attitudes by paying attention, caring, and respecting children's freedom, and guiding with understanding can create conditions for children to study music diligently both in theory and

\begin{tabular}{|c|c|c|c|}
\hline \multicolumn{4}{|c|}{ Correlations } \\
\hline & & $\begin{array}{l}\text { PARENTI } \\
\text { NG } \\
\text { PATTERN }\end{array}$ & $\begin{array}{l}\text { LEARNING } \\
\text { RESULTS }\end{array}$ \\
\hline \multirow[t]{3}{*}{$\begin{array}{l}\text { PARENTING } \\
\text { PATTERN }\end{array}$} & $\begin{array}{c}\text { Pearson } \\
\text { Correlation }\end{array}$ & 1 &, $308^{*}$ \\
\hline & Sig. (2-tailed) & &, 031 \\
\hline & $\mathrm{N}$ & 49 & 49 \\
\hline \multirow[t]{3}{*}{$\begin{array}{l}\text { PARENTING } \\
\text { PATTERN }\end{array}$} & $\begin{array}{c}\text { Pearson } \\
\text { Correlation }\end{array}$ & , 308* & 1 \\
\hline & Sig. (2-tailed) &, 031 & \\
\hline & $\mathrm{N}$ & 49 & 49 \\
\hline
\end{tabular}

practice. Thus, there is a positive and significant relationship between parenting styles and children's music learning outcomes.

Table 5 Results of the Correlation Test of Learning Interest with Learning Outcomes
Table 5 shows the results of a simple correlation test between the variables of interest in learning to the variables of learning outcomes in Music Art of 0.338 . These results show a positive number and the value of the correlation coefficient (r) in the study is included in the very strong category by referring to the interpretation of the correlation coefficient. At the 0.05 significance level, it is known that the significance value from table 4.19 is $0.00(0.00 \leq 0.05)$, so the correlation is said to be significant. The results of these calculations indicate that $\mathrm{Ha} 2$ is accepted, thus there is a positive and significant relationship between interest in learning and learning outcomes in Music.

\section{The Relationship between Parenting Patterns and Learning Interest on Music Learning Outcomes}

The correlation test in this study used a multiple correlation test with the help of the SPSS for Windows series 23 . program. The calculation results can be seen in the following table:

\begin{tabular}{|c|c|c|c|}
\hline \multicolumn{4}{|c|}{ Correlations } \\
\hline & & $\begin{array}{c}\text { Learning L } \\
\text { interest o }\end{array}$ & $\begin{array}{l}\text { Learning } \\
\text { outcome }\end{array}$ \\
\hline \multirow[t]{3}{*}{$\begin{array}{c}\text { Learning } \\
\text { interest }\end{array}$} & $\begin{array}{c}\text { Pearson } \\
\text { Correlation }\end{array}$ & . & ,33 \\
\hline & Sig. (2-tailed) & &, 0( \\
\hline & $\mathrm{N}$ & 6 & 6 \\
\hline \multirow[t]{3}{*}{$\begin{array}{l}\text { Learning } \\
\text { outcome }\end{array}$} & $\begin{array}{c}\text { Pearson } \\
\text { Correlation }\end{array}$ &, $338^{*}$ & \\
\hline & Sig. (2-tailed) & (00, & \\
\hline & $\mathrm{N}$ & 6 & 6 \\
\hline
\end{tabular}

Table 6

Correlation Test Results of Parenting Patterns and Interest in Learning with Learning Outcomes

Table 6 shows the results of the multiple correlation test between the variables of parenting and interest in the learning outcomes of Musical Arts is 0.615 . These results show a positive number and the value of the correlation coefficient (r) in the study is included in the strong category by referring to the interpretation of the value of $r$ (correlation coefficient). The results of these calculations indicate that $\mathrm{Ha} 3$ is accepted, thus, there is a positive and significant relationship between parenting and interest in music learning outcomes. 


\section{Siti Aesijah/JURNAL SENI MUSIK (10) (1)}

\section{CONCLUSION}

Based on the results of the research and discussion, the researchers concluded that there was a positive and significant relationship between parenting patterns and student learning outcomes of 0.308 with a small category. This shows that good parenting contributes $9.48 \%$ to student learning outcomes. The application of parenting with democratic attitudes by paying attention, caring, and respecting children's freedom, as well as guiding with understanding can create conditions for children to study music diligently, both in theory and practice. Thus, children's music learning outcomes can certainly increase.

In the interest variable, there is a positive and significant relationship between interest in student learning outcomes of 0.338 with sufficient category, student interest contributes $11.42 \%$ to student learning outcomes. High interest in learning will also affect learning outcomes.

There is a positive and significant relationship between parenting and interest in student learning outcomes of Musical Arts of 0.615 with sufficient category, student interest contributes $37.82 \%$ to student learning outcomes.

\section{REFERENCES}

Arief, S. (2006). Skizofrenia Memahami Dinamika Keluarga Pasien. Refika Aditama.
Hamdi, Asep Saepul. (2014). Metode Penelitian Kuantitatif Aplikasi Dalam Pendidikan. Yogyakarta: CV Budi Utama.

Kuswanti, A., Muqsith, M. A., Zainal, A. G., \& Oktarina, S. (2020). Manajemen Komunikasi Keluarga Saat Pandemi COVID-19. SALAM: Jurnal Sosial Dan Budaya Syar-I, 7(8), 707-722. https://doi.org/10.15408/sisbs.v7i8.15959

Ratna Ningrum, W. (2018). Pengaruh Peranan dan Pola Asuh orang tua Terhadap Hasil Belajar Siswa Sekolah Dasar Negeri ( SDN) di Kecamatan Bogor Barat.. Jurnal Pendidikan, 17(2), 129-137.

Slameto. (2015). Belajar dan Faktor-Faktor yang Mempengaruhinya. 6(8).

Sugiyono. (2017). Metode Penelitian Kuantitatif, Kualitatif, dan R\&D. Bandung : Alfabeta, $\mathrm{CV}$.

Suprijono. 2014. Cooperative Learning Teori dan Aplikasi PAIKEM. Yogyakarta : Pustaka Belajar.

Tridhonarto Al. 2014. Mengebangkan Pola Asuh Demokratis. Jakarta: PT Elex Komputindo. 